\title{
Visión de la Nueva Poesía del Brasil
}

\author{
(Conclusión)
}

\author{
Alvaro Moreyra
}

\begin{abstract}
WACIDO en 1888, en la progresista ciudad de Porto Alegre, Alva1 ro Moreyra representa - en lo más caracterizado de su laborel tono de sutil ironía, tan humano y saudoso. Desde Heine y Laforgue hasta Alfonsina Storni y Alvaro Moreyra, los poetas irónicos han sido siempre los grandes melancólicos. La sonrisa burlona es como la gota amarga que queda en el fondo de la copa de champaña. El estilo de Moreyra, que en sus comienzos presentaba afinidades con poetas simbolistas, ha evolucionado luego hacia expresiones más libres y sencillas, a la par que el elemento autóctono - no en su faz puramente objetiva, sino afinado por la emoción - ha dado mayor variedad y americanidad a la obra de este artista, iniciado en el mundo literario en 1911, con su tomo Leyenda de la luz y de la vida. Puede afirmarse que Alvaro Moreyra es de los poetas más sensibles del Brasil, lo que significa asegurar que es de los más humanos. Representa gallardamente, en la lírica total de su patria, el intelecto del Estado de Río Grande del Sur, tan culto e histórico.
\end{abstract}

\section{Murillo Mendes}

Este poeta, oriundo del Estado de Minas Geraes, afirma en una de sus más celebradas realizaciones:

No me juzguéis por mi palabra y mi sociedad.

Juzgadme por mi silencio y mi soledad. 
Debemos, sin embargo, afirmar que de la palabra poética de Murillo Mendes — la sociedad espiritual- surge un juicio altamente entusiasta de los méritos de este artista tan personal. Su obra no hay que buscarla únicamente en sus libros. Está también en un sinfín de revistas juveniles, a las que Murillo Mendes llevó su generoso fervor, su espíritu de lucha, su actividad ejemplar, en una labor vasta. en la que figuran, sin duda, poemas que en su hora fueron necesarios como carteles de renovación, pero que hoy restltan algo caóticos. Hay que reconocer, en definitiva, que se trata de un poeta noble y originalísimo, siempre ávido de nuevas zonas de lirismo denso y substancial, lo que lo señala con relieves singulares en el conjunto de poetas de su tierra, de la que es uno de los valores más apreciados y discutidos a la vez. De Murillo Mendes ha dicho un crítico brasileño: "Alguien querrá pegarle el rótulo de surrealista. Pero él se ríe. Desconcierta. Su poesía ya es profunda y seria como en las páginas de la época posterior a su conversión; ya revienta en el aire, vacío y frágil, como una pompa de jabón.."

\section{Menotti del Picchia}

Como Casiano Ricardo, es miembro de la Academia Paulista de Letras. $Y$ es una figura histórica en la lucha por imponer en San Paulo - allá, alrededor de los años 1919-23 - las conquistas de expresión de la nueva poesía universal, uniéndolas a las necesidades y originalidades propias de la sensibilidad brasileña. Reunió sus poemas en el tomo Lluvia de granizo, publicado en 1925, su libro inicial. En él figuran páginas como las tituladas "La callejuela", "E1 espejo", "Telaraña", "Lo que dicen las cosas", etc., de gran riqueza imaginativa y agudizada sensibilidad. Lo mismo puede afirmarse de sus Impromptus urbanos, donde la gran ciudad de San Paulo aparece en enfoques líricos muy originales. Tanto en su libro Lluvia de granizo como en Poemas de amor y otras obras, este autor revela genuinas. dotes de poeta fino, armonioso, entusiasta. Emplea con preferencia. el verso libre, y al referirse en un poema a la excesiva preocupación de estilo de Olavo Bilac, afirma:

Amabas demasiado la frase bonita, la rima complicada, 
y mi tierra es agreste, es áspera y morena,

$y$ el arte medido es pequeño

para cantar una patria demasiado grande.

Es de lamentar que otras actividades de Menotti del Picchia - especialmente la novela y el periodismo-- hayan distraído su atención por la labor poética.

\section{Oswaldo Orico}

Consideramos que es en las páginas de ese delicioso poemario titulado Danza de las luciérnagas, donde este cultísimo intelectual ha reflejado mejor su personalidad de poeta. De una musicalidad finísima, de un gran poder de sugestión, ese libro - publicado en 1923 - no adolece de ese exceso de vaguedad, de ese lirismo fácil e insubstancial que a menudo es "el contra" de muchos poemarios ricos en valores musicales. Su poema a Ouro Preto, la histórica ciudad del Estado de Minas Geraes, es de lo más valioso del libro, y se fija para siempre en nuestra memoria. La sutil espiritualidad de este libro de Orico, su lenguaje de ensueño, su inefabilidad, su sortilegio de imaginación, que anima e idealiza todo lo que toca, hacen evocar la bella afirmación de Pascal: "Dios ha representado, en las visibles, las cosas invisibles."

Debemos agregar también que Oswaldo Orico, miembro de la Academia Brasilera de Letras, es tuno de los intelectuales más eruditos de su patria, y que sus prosas poseen nervio y personalidad. Es este escritor un fervoroso americanista y realiza en su patria una vasta labor oficial en pro de la cultura y de la fraternidad continental. Es autor de varios eruditos estudios sobre la Amazonia, su tierra. Reside en Río de Janeiro.

\section{Oliveira e Silva}

Dedicado a los poetas de Recife, su ciudad natal, Oliveira e Silva publicó en 1922 su breve colección de poemas titulada Horizonte. Una sutil atmósfera de melancolía, de ternura humanísima, envuelve esos cantos y los que les siguieron, dos años más tarde, con el título 
general de El poema de la humildad. Ya en estas páginas se advertía una mayor ductilidad expresiva. Lo mejor de este poeta está en su libro El vuelo interrumpido (1930). Muy especialmente en la sección titulada "Alma de mi Brasil", Oliveira e Silva presenta poemas que - puede afirmarse sin temor de exagerar- figuran junto a los mejores de la nueva lírica del Brasil.

¡Qué profundización, qué exploración del alma autóctona, de sus mitos, de sus leyendas, de sus matices más originales y vivientes! ¡Y qué estilo fuerte y delicado a la vez, de una diafanidad y agilidad perfectas! Pero sería injusto que la preferencia de esta poesía de Oliveira e Silva silenciara el elogio de las otras páginas, de tono íntimo, de vehemente palpitación sentimental muchas veces, de concentrada riqueza conceptual. Actualmente este joven poeta, doctorado en Derecho, prepara la publicación de un nuevo poemario que, teniendo en cuenta sus genuinas dotes poéticas y su noble deseo de superación, ha de constituir sin duda, una fiesta lírica. Dicho libro llevará, posiblemente, el título de Sagitario.

\section{Raúl Bopp}

Como la casi totalidad de los colegas de su generación, Raúl Bopp expresa sus inquietudes líricas en versos libres, de ritmo personal. En sus poemas, el paisajista aparece siempre unido al emotivo. Gran artista, sabe captar los matices realistas de las cosas, pero al darles vida lírica, las jerarquiza con su intensa vibración estética y su humana ternura. Y ya nos hable de la "cunhantan" (doncella indígena) que se aproxima a las orillas del río paterno, o nos evoque aquella dolorosa vagabunda con fama de bruja, que pasaba entre el medio y la cruel ignorancia de los niños de un pueblito de cerros, Raúl Bopp se caracteriza por la virtud - no muy general en sus hermanos en arte - de condensar en pocos versos todo un mundo de sugestiones, de emociones, de imágenes. Es un hábil estilizador, un artista muy original, que posee densa cultura de las conquistas de la nueva poesía universal, especialmente en lo que a formas expresivas se refiere.

Bopp ha sido representante diplomático del Brasil en el Japón. 


\section{Carlos de Paula Barrios}

Nacido a orillas del Amazonas, en el simpático Estado de Pará, Carlos de Paula Barros se radicó en la capital de su patria. Pero la evocación de su magnífica tierra norteña ha estado siempre viva en su corazón. Es su terruño el que canta en las páginas de su primer libro, publicado en 1928, en Río de Janeiro, con el sugestivo título de Muirakitans (es decir, talismán que las Amazonas regalaban a los indios Guacaris, según la tan discutida leyenda). También hay visiones paraenses en su segundo libro Calendario (1930), donde Barros agrega una nueva faceta: la de lírico eminentemente subjetivo, faceta que rutila en las primeras poesías de dicho tomo. Es autor también del delicioso libro Teatro escolar (1934), modelo en su género. $Y$ de una larga leyenda indígena, versificada con verdadero arte: "Yaraporanga" (1935), leyenda inspirada en un relato que en la tribu Catania hicieron a Alvaro Arnoso de Mello Leitão. La generosa actividad de Carlos de Paula Barros produjo una obra de vastas proporciones: la traducción al portugués de Guarany, la. ópera inmortal que musicalizó el gran brasileño Carlos Gomes (183996) y que se ha representado con éxito en los grandes teatros líricos de todo el mundo.

\section{Padua de Almeida}

Es poeta de sentido social y de expresión ardiente y nueva, con algo de profético y de reivindicador. En este aspecto no llega nunca, felizmente, al tono discursivo y altisonante. Su seguro instinto estético lo aleja de esas zonas antipoéticas. $\mathrm{Y}$ una piedad sincerísima, caliente de humanidad, vibra siempre en lo más hondo de esos poemas. Ha dicho un crítico brasileño que Padua de Almeida, "el singular autor de $M i$ sombra - su impresionante estreno- y de ese reciente Instante universal, tiene una visión amplia y magnífica de la época actual, de la ansiedad y del clamor de los pueblos en el día de hoy".

Y Tasso de Silveira, el gran poeta y crítico, uno de los escritores católicos más valorados en el Brasil, ha afirmado con razón que "desde Castro Alves, el acento político universalista no vibró nunca con sonoridades tan vivas en la poesía brasileña, como en los poemas de Padua de Almeida". 


\section{Francisco Galvão}

\section{Dichoso tú, Anacreonte,}

que de la vida no conociste el dolor, sino el licor.

Así canta este poeta en una de sus más originales y sentidas composiciones. A su agilidad rítmica une su viva imaginación. Ê1 sabe bien que la poesía tiene su lenguaje propio - lenguaje de imágenes - en el que el hombre, en bondad de belleza, dice a sus hermanos su mensaje, en esta vida "mala y divina, terrible y dulce", que llamó un poeta.

Tienen los poemas de Francisco Galvão una línea armónica muy acentuada. Hay en ellos un perfecto equilibrio, sin que esto signifique que se trata de un poeta parnasiano. Al contrario. Una ardorosa y fina emotividad, tna sensibilidad agudizada y quintaesenciada, son presencia constante en las obras de Galvão, poeta eminentemente lírico, autor de esta armoniosa invocación:

Beethoven, joh mi hermano!, llora conmigo en la paz de las sombras, en el jardín sin rosas.

Poemas dedicados a la naturaleza del Brasil han denotado en Francisco Galvão gran vigor descriptivo.

\section{Carlos Drummond de Andrade}

En su fuerte contenido espiritual, el lirismo de Carlos Drummond de Andrade da una visión algo pesimista de la vida, visión siempre elevada e interesante. Intelectual atormentado y trascendente, refleja ese matiz poético que hallamos en todos los países, en todos los tiempos. En el conjunto lírico del Brasil, de voces quizá algo vehementes en su inspiración y demasiado opulentas de expresión, Drummond de Andrade se caracteriza por su sobriedad. Por ello, quizá podrá afirmarse que no es de los líricos representativos de la idiosincrasia tropical de su patria. (¿No fué Waldo Frank quien dijo que "La selva es la tonalidad y el símbolo de la naturaleza humana brasileña"?)

Representa Drummond el matiz espiritualista, el intelectualismo depurado, la sonrisa filosófica, la ironía melancólica. De su libro 
Alguna poesía, que publicó la editorial Pindorama, de Bello Horizonte, dijo Manoel Gahisto: "Las imágenes de la vida, trazadas con lápiz rápido, sugieren a menudo más de lo que muestran: tal es la poesía de este joven autor, que encierra en algunas palabras visiones justas y que se cuida de definir demasiado la emoción correspondiente."

\section{Wellington Brandão}

El "Psalmo a la raza venidera" es una de las más acabadas realizaciones de este poeta. En él -como en algunas de las más originales páginas de Padua de Almeida- el lírico se une al pensador, con algo de profeta. Pero - también como en Padua de Almeida - no cae el poeta en el tono enfático, pues logra que sus conceptos vivan siempre en un ambiente de auténtico lirismo. $\mathrm{Y}$ aunque quizá se halle a veces cierta afinidad con Walt Whitman, puede afirmarse también que los dos autores brasileños que aquí nombramos se expresan más musical y sutilmente, sin perder su brío vital. Como muchos de los líricos de su idiosincrasia, Wellington Brandão ha recurrido muchas veces a la prosa para decir su mensaje con más libertad. Su "Berceuse para la máquina rudimentaria", página originalísima, es bien representativa de la prosa de un alto poeta - prosa multicolor, multirritmica, de un enorme poder sugestivo, imaginativo y emotivo.

\section{Raúl Machado}

Afinado lirismo el de Raúl Machado. En él se hermana, a la limpidez de expresión, la música de las imágenes y un corazón caliente de humanidad. El poema "Indulgencia" define bien las características espirituales y técnicas de este artista. Vamos a traducirlo:

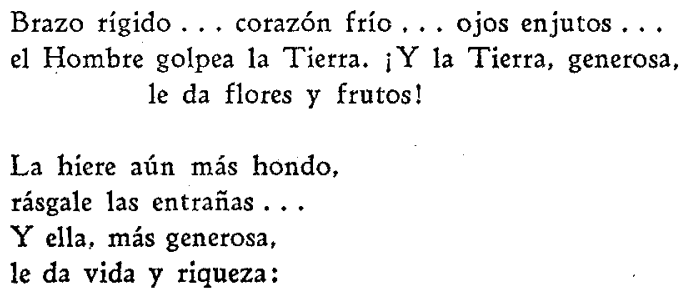


la salud del agua térmica,

el tesoro de los minerales

y de las piedras rutilantes...

El Hombre abre a la Tierra una ancha llaga viva

de muchos palmos de profundidad.

$\mathrm{Y}$ ella, de aquella llaga,

para calmar su sed le da su sangre.

Un día, el Hombre muere. $Y$ se le pone

el brazo más rígido,

el corazón más frío.

Y ella,

maternalmente, sin rencores

- idespués de tanta ofensa y tanto golpe!-,

lo recibe en su seno

y lo cubre de flores...

\section{Ildefonso Falcão}

Con opulencia e inspiración ha cantado la naturaleza de su patria. En sus poemas se siente el olor a la tierra llena de sol tropical. Esta objetividad se aúna muchas veces a la emoción humanísima del poeta, como en el canto evocativo "Viejo vaquero". Pero sin duda, la característica más saliente de Ildefonso Falcão es la poesía orquestal, luminosa, con algo de cascada rutilante. Así, el poema "Luz, mucha luz" debe citarse como una de sus más bellas realizaciones. Por algunas de sus facetas, recuerda Falcão, a veces, a Rudyard Kipling (al Kipling poeta de los "Songs of Empire"), superándolo Falcão por su mayor expresividad y exuberancia coloristica. A su vez, Kipling ha sabido enfocar mejor las figuras humanas y la sobriedad de su estilo se une a una mayor riqueza conceptual.

\section{Sergio Millet}

Ha realizado una inteligente y generosa labor en pro del conocimiento de la literatura brasileña en el extranjero, especialmente en la Revue de L'Amérique Latine de París. Comentarista fino y erudito, traductor comprensivo, ha vertido al francés muchas prosas $y$ poesías de autores brasileños contemporáneos, seleccionados con espíritu ecléctico. 
Su labor poética se caracteriza por la hondura del contenido emocional y conceptual. Conocedor de las modalidades expresivas de la poesia nueva, las ha asimilado con inteligencia y personalidad.

Su poema "Religión", de tono íntimo y extraordinaria sensibilidad, es una admirable realización, de un carácter poco común en la lírica brasileña. Es un breve monólogo, de sencillo tono familiar, desbrozado de todo prosaísmo, por la emoción del poeta y la limpidez del estilo. Fué elegido recientemente miembro de la Academia Paulista de Letras.

\section{Felipe d'Oliveira}

Como Alvaro Moreyra, procede del Estado de Río Grande del Sur. Se inició en la vida literaria más o menos al mismo tiempo que Moreyra. Su primer libro, Vida extinta, apareció en 1911.

Es Felipe d'Oliveira un poeta de rica vida interior. Si bien no se puede decir que pertenece al grupo simbolista - pues hay en su estética elementos de la escuela post-simbolista- su obra tiene muchas veces puntos de contacto con varios de los más ilustres poetas franceses que dan un valor primordial a la música del verso, a la emoción levemente esfumada, a la virtud de sugestión, tan cara a Mallarmé. La brasilidad de Felipe d'Oliveira está en su esencia anímica, en su saudade, ese sentimiento tan sutil y complejo de que ya hemos hablado... Evolucionó más tarde hacia corrientes de lirismo dinámico, de expresión surrealista.

Murió muy joven. Sus amigos fundaron una sociedad literaria con su nombre, en Río. Editan la lujosa revista Linterna verde.

\section{August Meyer}

Otro poeta gaucho, es decir, nacido en el Estado de Río Grande del Sur. Su ascendencia germánica no se transparenta en sus versos, de una gracia y emotividad realmente latinas. Sin duda, la influencia del maravilloso ambiente donde se desarrolla su existencia ha deslumbrado -anulándolo - todo avatar europeo.

Es Augusto Meyer uno de los líricos brasileños que con más entusiasmo han captado en su paleta lírica la multicolor fiesta de la naturaleza de su patria. Su temática vernácula es rica y original. 
Pintor y músico a la vez. $\mathrm{Y}$, como Flaubert, bien puede decir que "hay paisajes tan lindos, que uno desearía apretarlos junto a su corazón".

Su obra fundamental: Giraluz, editada en 1928, en Porto Alegre.

\section{Anisio Galvão}

Muerto en plena juventud y en pleno impulso de creación artística, este pernambucano no pudo realizar su obra con la intensidad de que era capaz. Pero lo que ha dejado es más que suficiente para darle un puesto de distinción en la lírica brasileña.

La mayor parte de su obra fué escrita alrededor del año 1924. En su creación lírica entran muchas veces elementos del ultraísmo de aquella época. Una entusiasta amistad con la más nueva poesía de aquel entonces, $y$ un viaje que realizó a Europa, contribuyeron sin duda a que se adviertan en la poesía de Anisio Galvão aspectos propios de la lírica europea y, más especialmente, francesa. Pero Anisio supo dar a su obra ese matiz personal, voz temperamental, que caracteriza al poeta verdadero. $\mathrm{Y}$ páginas suyas, como "Redención" y "Claro de luna" - algo extensa esta última-, son reflejos a la vez de una época literaria y de una individualidad lírica.

Evoquemos su figura como la de un genuino artista, un espíritu noble y fraterno y un fervor juvenil ávido de saber y de crear.

\section{Augusto Federico Schmidt}

Pájaro ciego, Navio perdido y Canto de la noche, son libros en que este poeta ha ofrendado su palabra musical, de una subjetividad intensa y densa.

No es Augusto Schmidt de los poetas más representativos de la sensibilidad brasileña. Su obra posee carăcter universal, quizá bastante europeo. Sus poemas "Oiremos la voz del otoño" y "Elegía" -creaciones recientes- confirman esa impresión, a la vez que revelan la marcha ascensional de este artista, tanto en la belleza de la expresión como en el emotivismo cada vez más transparente.

Lejos de nosotros el intentat reprochar a Federico Schmidt el carácter poco autóctono de su obra. Así como en su país viven ciu- 
dadanos venidos de todo el mundo, así su lirismo debe participar y participa del color universal, de ese amor universal que es sinónimo de humanidad.

\section{Ismael Nery}

Su lirismo es hermano del que se expresa en la tercera fase de Jorge de Lima, es decir, un neocatolicismo, en la búsqueda, el hallazgo y la prédica de la armonia entre lo humano y lo divino, el coro de lo celeste y lo terrestre, en una noble, dichosa y fecunda solidaridad. Como Rainer María Rilke, este poeta podía afirmar que "los versos son experiencias".

Ismael Nery falleció en 1934. Su obra dejó muchos discípulos. No es la suya una poesía para ser gustada por quienes prefieren el ritmo tintineante y los vocablos precisos. Es una poesía que se aparta de las rutas conocidas, en un arduo y muy loable afán de explorar nuevos mundos y traer su mensaje de verdad y de belleza. Tiene afinidades con Jacques Maritain. Su obra posee vida múltiple; nunca se agota su poder sugestivo. Es bien característico de su modalidad el breve poema titulado "La virgen inútill".

\section{Ascenso Ferreira}

Este pernambucano posee una personalidad artística muy diferente a la de Nery. Andrade Muricy dice con razón que "Ascenso Ferreira está en el límite entre la poesía y el canto popular". Su verso es sencillo, limpido, ondulante, nuevo. De él es esta deliciosa estrofa, brasilerísima :

Yo vi al Getrio de la Raza.

(Apuesto a que ustedes están pensando que voy a hablarles de Ruy Barbosa.)

No.

El Genio de la Raza que yo vi

fué aquella mulatita chocolate, ondulando en un baile frenético, el martes de carnaval. 


\title{
Rodovalho Neves
}

También es pernambucano, aunque bromea mucho menos que su coterráneo Ferreira. El libro de Neves titulado Casa vacía (1929) contiene poemas valiosos, tanto en el aspecto objetivo como en el subjetivo, tanto en la cuarteta de sabor popular como en la poesía refinada. Evoca a veces las "Doce canciones" de Maeterlinck. Por ejemplo, en este breve poema que traduciremos, "En aquella casa":

\author{
En aquella casa grande \\ vive mi sombra. \\ buscando mi pasado. \\ ¿Se habrá perdido el pasado \\ en esa casa tan grande, \\ en esa casa tan grande \\ -grande como nunca vi- \\ que te sirve de morada? \\ Debe de estar embrujada. \\ Mi sombra vive allí. \\ En esa casa tan grande.
}

Rodoralho Neves es miembro del Instituto Brasileiro de Cultura, de Río de Janeiro.

\section{Vinicius de Moraes}

Publicó este poeta, en 1935, su volumen Forma y exégesis, al que siguió, tres años más tarde, Nuevos poemas. Refleja su espíritu con la misma espontaneidad y armonía en el verso libre y en el soneto. Nosotros lo preferimos en el verso libre. Poeta subjetivo, tiene un noble anhelo de dar a su obra fuerza emotiva y riqueza de expresión. La labor ya realizada es bella y generosa, de honestidad artística. Cabe esperar aún obras superiores, teniendo en cuenta la juventud del autor y su entusiasmo por el arte.

En 1938 fué becado para realizar estudios en la Universidad de Oxford. 


\section{Theodomiro Tostes}

No es poeta fácil ni muy accesible. Evoca a veces a Juan Ramón Jiménez, no al de los romances nostálgicos o pastorales, ni al de los alejandrinos de Soledad sonora, sino al de los versos escritos después de Sonetos espirituales.

Andrade Muricy califica a Tostes de "neosimbolista" y dice que este poeta, en su obra, "parece alguien que entreviese un nuevo universo". $\mathrm{Y}$ así es, en efecto.

Para valorar ampliamente su lirismo, es necesario que el alma se abra igual que la rosa ávida de rocío.

Como Jules Supervielle, Theodomiro Tostes debe opinar, sin duda, que "la poesía es un grito secreto".

\section{Leão de Vasconcellos}

Es el Paul Geraldy de la poesía brasileña. Su libro Tatuajes sentimentales, publicado en 1933, y traducido más tarde al español por V. Lillo Catalán, es de un lirismo emotivo, leve, burbujeante, sedante. Su expresión es bastante sintética. Lo mismo puede decirse de Nuestra Señora de la Ausencia, tomo editado en 1936.

Leão de Vasconcellos procede del Norte, de la ciudad de Fortaleza.

\section{Rodrigues de Abreu}

Este poeta del Estado de San Paulo falleció en 1927, del mismo mal que se llevó a Chopin y a Samain. Su lirismo, de una gran nobleza, de una delicadeza admirable, refleja las gamas de un espíritu elevado, que no debe olvidarse. También en su poesía hay algo de Chopin. A veces evoca a Debussy, en su vaguedad soñadora, en su estilización depuradísima.

Este poeta de agudizada sensibilidad y vida melancólica, publicó los siguientes libros: Nocturnos (1919), La sala de los pasos perdidos (1924) y Casa destechada (1927). 


\section{Raúl de Leoni}

Otro poeta ya alejado de este mundo. Se inició en 1919 con su "Oda a un poeta muerto". Publicó más tarde Luz mediterránea (1922). De este libro existe una segunda edición (1928), en que se incluye la "Oda a un poeta muerto" y se recopilan varios "poemas inacabados".

De la lírica de Raúl Leoni destacamos su magnífico poema a Florencia - una de las más bellas páginas en elogio de la ciudad de la "Piazza de la Signoria"- y su alucinante "Nocturno". La poesía de este autor es austera y espiritual, apretadamente bella. Es como el coloquio de un alma atormentada de sabiduría, alma cristiana y pagana a la vez, que bebió ávidamente la copa de la vida y del arte. Junto a páginas breves y sonetos, hallamos en su obra poemas a la manera de torrenciales sinfonías. Hay en su poesía emoción humana muy noble, hondura filosófica, sentido cósmico.

\section{Lucio Cardoso}

Este poeta del Estado de Minas Geraes tiene en la actualidad veintiséis años de edad. Su primera obra, Maleita, apareció en 1934. Le siguió, dos años más tarde, Salgueiro. Son dos novelas.

A pesar de su juventud, Lucio Cardoso ha realizado ya una obra lírica de subidos quilates. En su labor aún no coleccionada en libro, se valora un poeta que, en el plano surrealista, consigue creaciones destacables por la agudeza de su sensibilidad, la novedad de sus bellas imágenes y lo denso de su lirismo. Son dignos de mención sus poemas "A una rosa" y "La llama nocturna".

\section{Otros poetas}

Francisco Karan es lírico de expresión sobria y viva sugestión. A veces, como en su breve poema "Sensaciones", tiene algo de epigramista. Ha escrito también magníficos versos místicos.

Poesía del hombre, libro de Mello Mourao, nos trae la vivencia de un poeta trascendente $\mathrm{y}$ vigoroso, con algo de Walt Whitman y Paul Claudel, en su ritmo sinfónico, en su acento profético, en su sentido cósmico. Tiene notas de misticismo. 
También Abgar Renault deja oír su voz mística, aunque de tono más íntimo que Mello Mourao. Su poema "Ignotus", al dios desconocido, es una de las más bellas oraciones líricas, de las más estremecidamente emotivas. La estética de Abgar Renault evoca a veces a Rabindranath Tagore, a quien ha traducido. Es también un sonetista admirable.

Aunque se destacó especialmente como ensayista, Néstor Víctor (autor de interesantísimos estudios de la personalidad de Novalis, Nietzsche, Maeterlinck, Ibsen, Whitman, etc.), dejó un libro de poemas titulado Trasfiguraciones, que debe recordarse por la nobleza de sus sentimientos y la riqueza de su estilo, características constantes en la obra de este notable brasileño.

Oliveira Ribeiro Netto, que pertenece a la Academia Paulista de Letras, ha publicado con éxito varios volúmenes de versos, de profunda emocionalidad. Su tomo más reciente es Estrella del alba, con grandes progresos en la pureza de la forma y la sutilización de los sentimientos. Saludamos en Ribeiro Netto a una personalidad poética en constante élan creador.

Manoel Maia Junior, fallecido muy joven, en 1927, cuando cursaba en Río estudios de Derecho, dejó una serie de poemas inéditos, muy finos y personales, que manos piadosas publicaron en 1929 , en un tomo titulado De la tristeza resignada. Lleva un bello prólogo de su amigo Cardilho Filho, poeta también, de quien debe hacerse una especial mención a su canto "América", en que exalta la grandeza y el destino del Continente que abre sus brazos fraternos a los doloridos del mundo.

Lacerda Pinto es un ensayista cultísimo y poeta de alta inspiración. Su poesía "Benedicte" refleja una emociỏn mística muy honda:

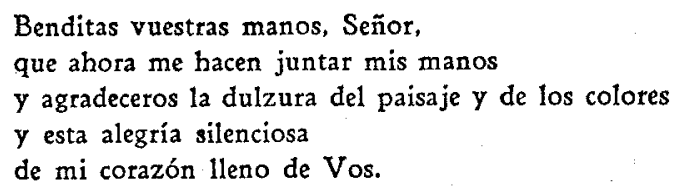

Benditas vuestras manos, Señor, que ahora me hacen juntar mis manos y agradeceros la dulzura del paisaje y de los colores y esta alegría silenciosa de mi corazón lleno de Vos.

Guilherme de Castro e Silva, que a los trece años de edad (1927) publicó, prologado por Ronald de Carvalho, su libro Alegría, es autor también de Poemas nuevos (1934), revelando grandes conquistas, tanto en la originalidad y belleza del estilo, como en la den- 
sidad de sus sugestiones emocionales. Este joven poeta se caracteriza también por su opulencia imaginativa. Refiriéndose a los Poemas nuevos, afirmó un crítico brasileño que "elogiaba, sobre todo, el equilibrio de un filón poético insistente y la música de medio tono, que denuncia la presencia del alma, aún insegura, aún tímida, pero ya impregnada de todos esos presentimientos y resonancias propios de la atmósfera de la poesía".

Los Cánticos bárbaros de Mario Cruz, que obtuvieron un primer premio de la Academia Brasilera de Letras, reflejan a un lírico que, en moldes clásicos de expresión, obtiene excelentes efectos por la agilidad de sus ritmos.

En suntuosa edición publicó Augusto de Almeida Filho, recientemente, sus 3 momentos de poesía, de los que destacamos, por su originalidad y musicalidad, los "Idilios árabes".

Harold Daltro dió a la estampa en 1928 La leyenda interior, libro al que siguió, en 1930, Flor del asfalto. El crítico francés Jean Duriau dijo de Harold Daltro: "Hay una gran sinceridad ingenua en este joven poeta que ha sabido trasmitir a ciertos temas banales una renovación de vida, de alegría y de tierno encanto."

Un vigoroso talento descriptivo reflejan los poemas de Silveiro Netto. Su tríptico Fronda al sol es como una alucinante aguafuerte de la selva brasileña.

Solón Borges dos Reis, que ejerce el magisterio en el Estado de San Paulo, es autor del tomo de versos titulado Apostasía, que apareció en 1936. Revela un noble temperamento, de expresión espontánea. Pertenece también al Estado de San Paulo Ibrantina Cardona, cuyo mejor libro, Alas rubras, apareció en 1939. Es poetisa vehemente, colorista y conceptual a la vez. En algunas ocasiones explora la veta de los motivos autóctonos. Otra inspirada poetisa es Walkyria Neves Goulart, viuda del muy erudito escritor Jorge Salis Goulart. Walkyria ha enriquecido, con su poesia refinada y musical, el coro lírico del Estado de Río Grande del Sur, en el que figuran valores tan altos como Ernani Fornari, poeta de rica vibración humana y armonía expresional.

La Rapsodia gaucha de Flavio da Silveira posee las buenas cualidades de la epopeya y está libre de los defectos inherentes a ese género de poesía. Merece destacarse por ser una nota no muy corriente en la poesía brasileña, que, en general, tiene el acierto de evitar los poemas de excesiva extensión, porque sabe que la síntesis —que de 
ninguna manera está reñida con la riqueza formal o conceptual- es una de las más grandes conquistas de la nueva poesía.

Nacido en el Estado de Río Grande del Sur, Vicente Fittipaldi escribió sus más bellos versos durante su residencia en la ciudad de Recife. Sus poemas autóctonos son sabrosos como frutos del trópico. También es de Río Grande Waldemar de Vasconcelos, temperamento ecléctico, que sabe valorar estéticamente la vida y la naturaleza. Es, asimismo, ensayista cultísimo. Reside en Río.

En 1927 publicó Pedro Vergara, en la ciudad de Porto Alegre, su libro Tierra impetuosa, que dedicó a todos los poetas nuevos. Sus versos, de gran libertad y variedad rítmicas, están estriados de imágenes magníficas.

María Eugenia Celso, hija del eminente Conde Alfonso Celso, es autora de poemas delicados y emotivos. Creemos, sin embargo, que es Vicentito, muy hermoso libro en prosa, donde esta artista ha realizado su obra más interesante y original.

Al Estado de Minas Geraes -de donde son originarios Murillo Araújo, Murillo Mendes y Carlos Drummond de Andrade, cuyas características ya hemos apuntado- pertenece Heli Menegale. En el aspecto general de la lírica brasileña, quizá demasiado sonora y colorida - y esta característica es, en el caso del Brasil, una virtud, no sólo porque posee quilates estéticos, sino también porque representa un valor original, racial-, Heli Menegales se destaca por la línea severa y austera. Su poesía es íntima, personal, a media voz, muy lírica, muy fraterna. Recuerda a veces a Amado Nervo. Emilio Moura, más impetuoso, sabe dar a sus creaciones un sentido trascendente, penetra la entraña de las cosas, y su hondura conceptual no amengua la vibración emotiva de su canto. Muy distinta de la de Moura es la personalidad de Djalma Andrade, en chyo lirismo burbujeante se refleja la vida cotidiana, con sus sonrisas y sus lágrimas. Casi desconocido es J. Edson de Melo, auténtico poeta, que reside en un pueblito. De las voces más brasileñas de Minas Geraes, debemos citar a Melo Macedo y Vinicius Meyer. El primero es un paisajista admirable, de un suntuoso cromatismo. Vinicius Meyer explora más el sentido racial y en sus poemas, tras el elemento objetivo, palpitan la saudade y la leyenda. Newton Beleza es poeta multifacético. Achilles Vivaqua publicó en 1928 una plaquette titulada Serenidad, en cuyas páginas supo animar, con un soplo de lirismo, las cosas humildes, sencillas, silenciosas. De ese libro preferimos el 
"Nocturno de Bello Horizonte". Malo Cancado es poeta místico, grave, fino.

Entre las poetisas de Minas Geraes se destaca Henriqueta Lisboa, espíritu esencialmente soñador, ajeno a la gran sinfonía luminosa de su tierra. Ama la penumbra, las flores deshojadas, el silencio, la mansedumbre. Su lirismo, que resultaría falto de vida, se enriquece con una alta nobleza espiritual. De un temperamento semejante al de Henriqueta Lisboa es Carminha S. Gouthier, cuya poesía es, a veces, místico sahumador. En general, puede afirmarse que los poetas de Minas Geraes son los que con más asiduidad cultivan la poesía subjetiva, íntima, muchas veces religiosa. Ello se explica, por tratarse de una región situada en la altiplanicie, de muy frecuentes neblinas.

De Bahía, el Estado cuya simpatiquísima capital es, junto a sus grandes progresos edilicios, un museo de las tradiciones coloniales y una viviente estampa afro-brasileña, patria del gran poeta Castro Alves - es Carvalho Filho, autor de un bello poemario titulado Integración, del que dijo un crítico brasileño: "La gran plasticidad, la flexible receptividad de la adolescencia, refléjanse en este libro, con un ancho movimiento de aguas irisadas." Son también oriundos de Bahía: Eugenio Gomes, uno de los más grandes poetas de ese Estado; Godofredo Filho, cuyo lirismo posee una alta sugestión de símbolo; Pinheiro de Lemos, noblemente melancólico, y Rafael Barbosa, que canta así a la vida:

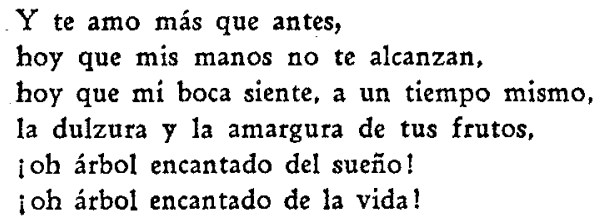

También de Bahía es Hildeth Favilla, poetisa que, siendo muy joven, publicó su libro titulado Dolor suave, al que siguieron Sarabanda iluminada y Cascabel de oro. Su poesía leve, espontánea, posee una gracilidad muy femenina.

Subiendo el mapa del Brasil, llegamos a Pernambuco. De alli proceden, como hemos visto, Manuel Bandeira, Adelmar Tavares, Olegario Mariano, Rođovalho Neves, Ascenso Ferreira. Tambiẻn pertenece a Pernamb zo Joaquín Cardozo, de quien debemos desta- 
car su poema a "Recife muerto". Es como un epitafio para todas las ciudades que van perdiendo su carácter, su personalidad y su gracia, en el voraz avance de la urbanización. También de Pernambuco son Gilberto Freyre y Austro Costa. El primero ha dado notas de una plasticidad, brío y fina ironía, muy de su tierra. El segundo, de una labor un tanto desigual en sus valores, es autor de poemas muy apreciables, por su pureza juvenil y su entusiasta lirismo.

Y más allá, en tierras cearenses, Antonio Girao Barroso y Sinó Pinheiro, autores, respectivamente, de los libros Algunos poemas y Evangelización.

Y en Cuyabá, donde la jungla del Estado de Matto-Grosso clava el verdor de sus garras, José de Mesquita dice su inquietud anímica en versos de forma correcta.

\section{La generación novísima}

Encabezaremos este desfile con el nombre de Ivan Ribeiro, cuyo libro Aleluya, publicado en 1937 bajo la advocación luminosa de Jorge de Lima, posee méritos más que suficientes para considerar a este poeta, no ya como una promesa, sino como una hermosa realidad. Tiene su libro una madurez rara de hallar en la obra primigenia de un poeta.

Otros poetas novísimos: Alfonsus de Guimaraes y Nazareno Alfonsus, ambos hijos del poeta parnasiano Alfonsus de Guimaraes; Etiene Filho y Milton Amado, de noble vibración mística. E1 lirismo de Violeta Branca, joven poetisa nacida en Manaos, en plena Amazonia, es espontáneo y claro, muy femenino. Recuerda a veces a la Juana de Ibarbourou de El cántaro fresco y Raíz salvaje.

Debe hacerse una especial mención del poeta Manuel Albano Amóra, que en la ciudad atlántica de Fortaleza, en el Estado de Ceará -el Estado del glorioso José de Alemcar-, publicó en 1938 su primer libro, titulado Mañana de amor, en que se destacan dos poemas muy emotivos: uno a Cristo, otro a Chopin. Como la mayor parte de los poetas novísimos, Albano Amóra cursa en la actualidad estudios universitarios.

Son también estudiantes los componentes del grupo "Generación", de Recife, de los que hablaremos a continuación, comenzando por Mario Souto Mayor, que en 1938 publicó un bello libro con el 
título de Mis poemas diferentes. Souto Mayor canta con deliciosa saudade las cosas humildes y puras de la vida: los lirios del campo, las campanas cuya voz recuerda los días de la infancia, el dolor negro de los esclavos. La parte más substancial de esa colección de poemas es, a nuestro juicio, la que se agrupa en páginas que tienen un sutil tono folklórico, como "Sinos" y "Eu vou p'ra cas".

El "Himno al sertão" (es decir, a los lugares del interior del país, alejados de los centros de civilización), del que es autor Luis Gonzaga Santos, es una especie de orquestación exaltadora de la belleza, grandiosa y sencilla a la vez, de la vida sertaneja. Gonzaga Santos conoce y ama el sertão, al que llama "reserva heroica de brasilidad". En su libro vemos y oímos el sertão.

Guerra de Holanda posee un temperamento artístico muy diferente del de Gongaza Santos. Es un poeta sintético, que gusta de concentrar sus ideas emocionales en pocos versos. Es, en lo espiritual, un irónico melancólico. (Siempre la sonrisa es, en los poetas, un poco triste.) Muy bellos poemas contiene el libro Audacia, que Guerra de Holanda publicó en 1938.

Otros poetas de esta novísima generación: Pelópidas Soares, cuyo poema "Catendé" es una acuarela muy bien realizada. Anuncia su primer libro: Luz de la vida. Otros jóvenes también, o mejor, adolescentes, sueñan con la publicación del tomo querido que reunirá sus poesias: Demóstenes Soares, que gusta, como Guerra de Holanda, de la expresión sintética; Isaac Schachmick y S. Leão Netto.

La poesía moderna del Brasil, ya refleje el colorido jugoso de su naturaleza, ya nos lleve a zonas de fina emotividad, ya evoque mitos y leyendas o avizore la luminosidad de un porvenir mejor, se caracteriza por su acento humano. Es, en lo más bello de su perfil, una. poesía de carácter nacionalista. Pero su nacionalismo no se encierra en fronteras, sino que busca sendas de fraternidad continental $\mathrm{y}$ universal. Como hemos visto, no falta, en la fiesta lírica del Brasil, el grupo de poetas que podrían pasar por autores extranjeros. Son los menos, es cierto, pero ello demuestra la amplitud de espíritu, la riqueza de facetas de esa lírica, la variedad de voces, que se unen formando un coro muy armonioso.

$\mathrm{Y}$ ya en los de tono humilde y popular, como en los de más suntuosa y refinada expresión, los poetas de ese gran país poseen una tensa vibración emocional, un generoso fervor de humanidad. Por eso puede afirmarse que estos artistas realizan con nobleza y 
belleza la verdad del pensamiento de Rodolfo Binding: "Los poetas son quienes hablan el lenguaje maravilloso para el cual el pueblo es mudo, pero que, cuando lo oye en boca del poeta, lo reconoce como el suyo propio."

Gastón Figueira, Montevideo. 
